\title{
Peran Front Desk dalam Peningkatan Pelayanan Prima di Unit Program Belajar Jarak Jauh, Universitas Terbuka Medan
}

\section{The Role of Front Desk in Improving Excellent Service in the Distance Learning Program Unit, Medan Open University}

\author{
Sihar Pandapotan ${ }^{1 *}$ \& Trisni Andayani2) \\ 1) Unit Program Belajar Jarak Jauh, Universitas Terbuka Medan, Indonesia \\ 2)Program Studi Pendidikan Antropologi, Fakultas Ilmu Sosial, Universitas Negeri Medan \\ *Coresponding Email: siharpandapotan@gmail.com
}

\begin{abstract}
Abstrak
Penelitian ini mengenai peran dan standar pelayanan pegawai Front Desk dalam peningkatan pelayanan prima, kendala yang muncul dalam melaksanakan pelayanan prima yang sesuai dengan SOP, apa saja jenis keluhan customer dan solusi yang diberikan dan saran serta harapan customer dalam rangka peningkatan kualitas UPBJJUT Medan. Hasil penelitian menunjukkan bahwa Layanan baru yakni pengangkatan TKT front desk diperlukan dalam rangka pengoptimalan kinerja yang sesuai dengan visi, misi, tujuan, dan sasaran Universitas Terbuka. Peran pegawai front desk di UPBJJ-UT Medan sangat penting karena sepanjang masa 2016.1, setidaknya ada 1.005 orang mahasiswa yang terbantu dalam penyelesaian masalah studinya. Melalui penempatan front desk di tiap UPBJJ, telah membantu kelancaran berbagai permasalahan yang dialami mahasiswa dalam penyelesaian studinya.

Kata Kunci: Peran Front Desk, Peningkatan, Pelayanan Prima
\end{abstract}

\begin{abstract}
This research is about the role and service standards of Front Desk employees in improving excellent service, obstacles that arise in carrying out excellent services in accordance with the SOP, what types of customer complaints and solutions provided and customer suggestions and expectations in order to improve the quality of UPBJJ-UT Medan. The results showed that the new service, namely the appointment of TKT front desk is needed in order to optimize performance in accordance with the vision, mission, goals and objectives of the Open University. The role of front desk staff in UPBJJ-UT Medan is very important because throughout 2016.1, there were at least 1,005 students who were helped in solving the problem of their studies. Through the placement of a front desk at each UPBJJ, it has helped smooth the various problems experienced by students in completing their studies.

Keywords: Role of Front Desk, Improvement, Excellent Service
\end{abstract}

How to Cite: Pandapotan, S. \& Andayani, S. (2019). Peran Front Desk dalam Peningkatan Pelayanan Prima di Unit Program Belajar Jarak Jauh, Universitas Terbuka Medan. Journal of Education, Humaniora and Social Sciences (JEHSS). 2 (1): 119 - 130.

\section{PENDAHULUAN}

Front Desk merupakan etalase dan citra institusi Universitas Terbuka yang memiliki peran sangat penting dalam upaya pengoptimalan kinerja dalam rangka mencapai visi, misi, tujuan, dan sasaran universitas. Universitas Terbuka sebagai salah satu Perguruan Tinggi Negeri di Indonesia bekerja keras untuk dapat melaksanakan peningkatan pendidikan di Indonesia, khususnya pada UPBJJ-UT Medan. Salah satu upaya implementasi peningkatan tersebut terlihat dari dibukanya layanan baru yang lebih efektif antara customer (mahasiswa) dengan pihak UT yaitu dengan menghadirkan layanan front desk. Upaya ini telah dilakukan mulai tahun 2015 lalu. 
Pegawai front desk harus menyelesaikan masalah customer dengan tuntas. Ia juga dituntut untuk tidak pernah mengatakan tidak tahu dan memperlihatkan raut wajah yang ragu kepada customer. Di sisi lain, ia tidak diperbolehkan menyudutkan dan mempermalukan customer dan Universitas Terbuka. Customer tidak boleh dibiarkan menunggu lama, apalagi dalam ketidakpastian terkait informasi yang diharapkannya. Sehingga seorang pegawai front desk haruslah memiliki sikap profesional, santun, tepat dan akurat, empatik, informatif, edukatif, dan persuasif.

Dengan banyaknya tuntutan pada pegawai front desk, tentunya ia harus senantiasa meng-update kapasitas dan kapabilitas dirinya, mengetahui dengan benar seluk beluk Universitas Terbuka, baik cabang maupun pusat, juga memahami setiap mekanisme peraturan baru yang diterapkan oleh UT. Memberikan pelayanan yang baik dalam rangka menjaga kenyamanan mahasiswa adalah kewajiban setiap Perguruan Tinggi yang tentunya sesuai dengan peraturan perundang-undangan.

Kebutuhan setiap mahasiswa tentunya berbeda-beda sehingga dalam pemenuhan kebutuhannya juga berbeda. Di dalam menyampaikan kebutuhan dan keinginan tersebut ada kalanya mahasiswa menyampaikan saat mereka melakukan pendaftaran dan keluhan menyangkut nilai dan sebagainya. Pelayanan yang baik dan prima merupakan salah satu ranah yang dibutuhkan mahasiswa untuk memahami universitasnya. Sebab dengan adanya pelayanan prima, mahasiswa dan customer lainnya merasakan kenyamanan menempuh pendidikan di perguruan tinggi tersebut.

Terkait dengan tuntutan yang yang harus dipenuhi oleh seorang pegawai front desk tentunya harus dianalisis kendala-kendala yang dihadapi oleh seorang front desk di lingkungan Universitas Terbuka agar ditemukan solusi yang tepat untuk memecahkan masalah tersebut. Hal ini mengingat masih barunya model pelayanan prima yang diterapkan oleh UT dan masih barunya pegawai TKT front desk yang dipekerjakan. Oleh karena itu diperlukan sebuah penelitian yang ditujukan pada pegawai front desk dan customer yang mampu mengakomodir semua permasalahan yang ada di pokjar-pokjar seluruh Sumatera Utara, sehingga pengoptimalan informasi terkait UT dapat tersampaikan kepada mahasiswa di masing-masing pokjar.

Universitas Terbuka merupakan salah satu perguruan tinggi negeri yang terdapat di Indonesia. UT sendiri merupakan PTN ke-45 di Indonesia dengan sistem PTTJJ (Pendidikan Tinggi Terbuka Jarak Jauh ). Saat ini UT telah berdiri selama 32 tahun, 
tepatnya sejak 04 September 1984 dengan Keppres RI No. 41 Tahun 1984. UT memiliki empat fakultas, yaitu Fakultas Ekonomi (FEKON), Fakultas Ilmu Sosial dan Ilmu Politik (FISIP), Fakultas Matematika dan Ilmu Pengetahuan Alam (FMIPA), Fakultas Keguruan dan Ilmu Pendidikan (FKIP) dan satu program Pascasarjana. UT didirikan untuk memberikan kesempatan bagi siapapun guna mendapatkan pendidikan tinggi tanpa dibatasi oleh usia, pekerjaan, dan lokasi tempat tinggal (Katalog UT, 2015:1).

UT memiliki visi menjadi institusi PTTJJ berkualitas dunia dalam menghasilkan lulusan pendidikan tinggi yang memiliki daya saing tinggi serta dalam mengembangkan teori dan praktek PTJJ. Sedangkan misi UT ialah (1) menyediakan akses pendidikan tinggi yang berkualitas dunia bagi semua lapisan masyarakat melalui penyelenggaraan berbagai program PTTJJ untuk menghasilkan lulusan yang berdaya saing tinggi, (2) mengkaji dan mengembangkan sistem PTTJJ, (3) memanfaatkan dan mendiseminasikan hasil kajian keilmuan dan kelembagaan untuk menjawab tantangan kebutuhan pembangunan nasional.

Universitas Terbuka memberikan pelayanannya di tiap daerah yang diselenggarakan oleh UPBJJ-UT. Unit Program Belajar Jarak Jauh (UPBJJ) adalah salah satu unit pelaksana teknis di daerah yang terbagi pada 39 kantor UPBJJ UT seluruh Indonesia yang siap melayani mahasiswa seluruh Indonesia bahkan sampai ke luar negeri. Adapun fungsi dan tugas UPBJJ-UT adalah sebagai wadah bagi mahasiswa untuk melakukan kegiatan administratif akademik dan kegiatan akademik. Untuk kegiatan sehari-hari, UPBJJ-UT mempunyai tugas penyelenggaraan pelayanan belajar jarak jauh.

Pada saat awal berdirinya Kantor UPBJJ-UT Medan, Sumber Daya Manusia (SDM) penyelenggara kegiatan operasional kantor dimulai dari Kepala UPBJJ, Ketua Program, Kasubbag Tata Usaha, Bendahara dan seluruh pegawainya masih memberdayakan SDM yang berasal dari staf IKIP Negeri Medan dengan status PNS yang diperbantukan (dpk) di UPBJJ-UT Medan dan berkantor di lahan milik IKIP Medan yang sekarang telah berubah namanya menjadi Universitas negeri Medan (Unimed).

Saat ini UPBJJ-UT Medan telah memiliki lahan dan kantor sendiri di Jl. Bromo No. 29 Medan dengan struktur adanya kepala UPBJJ-UT, Kasubbag-TU, Koordinator Registrasi dan Ujian, Koordinator BBLBA, staf edukatif dan administrasi yang keseluruhan PNS-UT.

Sebagai salah satu unit pelaksana teknis, UPBJJ-UT Medan mengikuti fungsi strategis Universitas Terbuka, yakni: (a) memberikan layanan keluhan dan informasi 角hth: http://mahesainstitute.web.id/ojs2/index.php/jehss 
dengan uraian (1) menjawab informasi ke-UT-an, (2) merespon pertanyaan, keluhan, dan permasalahan dalam mengikuti studi di UT; (b) melakukan sosialisasi dan membangun kedekatan hubungan yang uraian (1) diseminasi informasi/ edukasi publik, (2) penyapaan, pengumuman, (3) follow up pengunjung pameran, dan (4) pemasaran digital.

\section{METODE PENELITIAN}

Metode penelitian yang digunakan ialah kualitatif deskriptif. Metode kualitatif deskriptif adalah upaya yang dapat menjabarkan secara jelas terkait data-data yang dibutuhkan dalam penelitian seperti standar kerja pegawai front desk, kendala - kendala yang dihadapi di front desk UT, dan berbagai keluhan dan solusi yang diberikan kepada customer oleh pegawai front desk.

Pada penelitian ini telah dilaksanakan teknik pengumpulan data berupa observasi, wawancara, dan analisis data keluhan secara kuantitatif. Teknik ini adalah cara yang ampuh untuk digunakan agar dapat memeroleh data yang valid. Selain itu, penelitian juga didukung dengan teknik dokumentasi sebagai cara untuk memeroleh informasi yang lengkap dan menyeluruh sesuai dengan fakta yang terjadi.

Data pertama kali diperoleh berdasarkan hasil pengamatan di sekitar area front office. Observasi dilakukan dengan pengamatan terlibat, juga sambil lalu. Semua kegiatan dan aktivitas yang dilakukan/ dikerjakan oleh pegawai front desk dipantau secara berkesinambungan untuk memeroleh data - data yang valid terkait pertanyaan penelitian.

Selanjutnya, melakukan wawancara. Wawancara dilakukan secara formal dan informal. Secara formal dilakukan dengan mengajukan berbagai pertanyaan secara struktural dan runut kepada para informan. Sedangkan secara informal dilakukan melalui komunikasi via jejaring sosial untuk mempertanyakan ulang pembahasanpembahasan yang belum diperoleh.

Selain observasi dan wawancara, juga dilakukan teknik dokumentasi sebagai bukti nyata berlangsungnya kegiatan pelayanan prima oleh pegawai front desk dengan menggunakan media handphone dan camera. Data-data tersebut kemudian dihimpun untuk dapat diolah dalam teknik analisis data. 
Teknik analisa yang dilakukan dalam penelitian ini adalah analisis data model kualitatif seperti yang pernah dilakukan oleh Miles dan Huberman (dalam Iskandar, 2009) yang terdiri dari tiga kegiatan yaitu: Reduksi data, Data yang diperoleh dari lokasi penelitian atau data lapangan yang tertuang dalam uraian yang lengkap dan terperinci. Penyajian Data, data penelitian dapat dianalisis oleh peneliti untuk disusun secara sistematis, sehingga data yang diperoleh dapat menjelaskan atau menjawab masalah yang diteliti, Penarikan Kesimpulan, setelah hasil penelitian telah diuji kebenaranya, maka peneliti dapat menarik kesimpulan dalam bentuk deskriptif sebagai laporan penelitian.

\section{HASIL DAN PEMBAHASAN}

\section{Peran dan Standar Pelayanan Pegawai Front Desk}

Seorang pegawai front desk dituntut untuk senantiasa dapat memberikan pelayanan prima bagi pelanggannya. Sebagaimana pernyataan Damon Richards yang disampaikan oleh PPSDM dalam Pelatihan Pelayanan Prima bagi Pegawai Front Desk UPBJJ-UT, bahwa "Customer tidak peduli betapa pintarnya Anda, sampai mereka mengetahui betapa perhatiannya Anda kepada mereka". Pernyataan tersebut berarti menuntut para pegawai front desk UPBJJ-UT Medan untuk dapat memberikan perhatian dan kepeduliannya dengan baik atas permasalahan terkait studi mahasiswa di UPBJJ UT medan.

Agar pegawai front desk memahami tupoksinya di Universitas Terbuka, maka oleh pimpinan UT melalui Kepala Pusat Pengembangan Sumber Daya Manusia (PPSDM) UT telah melakukan pelatihan pelayanan prima pada para pegawai front desk. Pada kegiatan tersebut, pegawai front desk dituntut untuk memahami peran, tanggung jawab sebagai pegawai front desk UPBJJ dalam memberikan pelayanan prima kepada pelanggan. Mereka juga harus mengenal tipe dan karakter pelanggan serta mampu menanganinya, meningkatkan keterampilan komunikasi baik pada situasi normal maupun situasi sulit, membuat rencana penerapan untuk meningkatkan layanan di tempat kerja, memahami kurikulum dan pedoman akademik di UT, dan program - program/ aplikasi yang diluncurkan oleh UT.

Berikut ini diuraikan satu persatu hal-hal yang harus dipahami oleh seorang pegawai front desk dalam pelatihan pelayanan prima bagi Pegawai Front Desk di UPBJJ- 
UT, yaitu Memahami Sistem Pendidikan di Universitas Terbuka, dimulai dari visi, misi, tujuan, sistem pembelajaran, sistem registrasi UT, biaya pendidikan, bahan ajar, bantuan belajar, evaluasi hasil belajar, kelulusan, ketentuan umum administrasi akademik, kemahasiswaan dan alumni, maupun program akademik. Hal - hal tersebut dapat dipelajari seorang pegawai front desk, baik secara lisan (arahan pelma, pelatihan) maupun secara tertulis (katalog Universitas Terbuka). Hal ini bertujuan agar customer dapat merasakan kepuasan layanan administrasi yang diberikan oleh Universitas Terbuka secara optimal dan profesional.

Selain pegawai front desk dituntut memahami segala seluk beluk Universitas Terbuka, ia juga harus mampu memahami konsep layanan prima. Hal ini berarti pegawai front desk dapat memberikan pelayanannya kepada institusi dan customer secara prima dan profesional. Pada sisi perusahaan/organisasi, pegawai front desk bertugas memenuhi kebutuhan dan harapan customer, bahkan jika mungkin bisa melampauinya. Sedangkan pada sisi customer, pegawai front desk harus memberikan semua kebutuhan dan harapan yang dibutuhkannya. Customer dalam hal ini ialah siapapun yang membutuhkan bantuan front desk, siapapun yang dibutuhkan untuk kelancaran pekerjaan, seperti rekan kerja, dosen, mahasiswa, orang tua mahasiswa, dan lain-lain.

Hal lain yang perlu berjalan beriringan ialah pegawai front desk dituntut memiliki keterampilan interaksi layanan. Distorsi komunikasi atau kekurangtepatan dalam berkomunikasi dapat menjadi faktor penghambat komunikasi yang efektif. Hal ini ditengarai oleh tiga faktor yang dapat memperlancar dan memperlambat komunikasi yakni fisik, psikologis, dan semantik. Faktor fisik ialah kondisi fisik, kondisi lawan bicara, jarang, suasana (keributan), dan layot ruangan. Faktor psikologi ialah suasana hati, perasaan/mood, tingkat percaya diri, persiapan, kematakan berpikir, dan stress. Faktor semantik seperti jargon, istilah, kata-kata, dan maksud.

Situasi sulit ialah reaksi negatif customer yang disampaikan kepada penyedia jaa layanan karena customer merasa mendapatkan layanan yang tidak sesuai dengan kebutuhan dan harapannya. Komplain muncul sebagai akibat dari terjadinya kegagalan layanan. Customer menginginkan komplainnya didengarkan dan disimak, mendapat layanan yang lugas dan tidak berbelit-belit (tidak dioper ke bagian-bagian lain), dan mendapatkan alternatif solusi dari permasalahan segera. Dalam kondisi seperti ini, pegawai front desk diharapkan dalam menjadi garda pertama yang dapat memberikan 
solusi cepat dan tidak bertele-tele, menjadi part of solution, bukan parts of problem, jujur, tidak over promise, namun tidak pula berkata 'tidak' kepada customer (willingness to help).

Seorang pegawai front desk juga dituntut mampu memahami pedoman akademik di UPBJJ-UT Medan. Hal ini tidak terlepas dari banyaknya keluhan diperoleh dari para mahasiswa berkaitan dengan alur akademik. Sehingga memahami konsep akademik di UT, adalah cara untuk dapat menyampaikan solusi atas keluhan yang disampaikan customer.

Penguasaan materi terkait ranah akademik, dapat dipelajari oleh pegawai Front Desk, baik melalui berbagai pelatihan yang diberikan UT maupun mempelajarinya secara langsung, misalnya membaca Katalog Sistem Penyelenggaraan Program Pendas, NonPendas, pascasarjana UT, memahami isi Rencana Strategis, Rencana Operasional, UT, memahami alur layanan program pendidikan, proses bisnis bidang akademik, kurkulum UT, bahan ajar, layanan bantuan belajar-praktek/praktikum, tutorial, karil, proses ujian baik manual maupun online, tugas matakuliah, dan hal-hal terkait lainnya.

\section{Kendala yang Dihadapi Pegawai Front Desk}

Sesuai dengan Peraturan Menteri Pendidikan Nasional No.23 tahun 2007 tentang Statuta UT, pasal 94 poin (2) bahwa UPBJJ-UT mempunyai tugas melaksanakan layanan bantuan belajar, layanan administrasi akademik, pendistribusian bahan belajar kepada mahasiswa, pelaksanaan ujian, praktek dan praktikum serta pengiriman nilai ujian kepada mahasiswa dan penyerahan ijazah serta kegiatan kemahasiswaan.

Oleh karena itu, pegawai front desk tentu berperan serta dalam kelancaran tugas tersebut. Pada umumnya, tupoksi seorang pegawai front desk adalah menerima keluhan dan menyampaikan keluhan tersebut ke bagian Koordinator Registrasi dan Pengujian serta Koordinator Bantuan Belajar dan Layanan Bahan Ajar (BBLBA). Selain itu adalah menyampaikan informasi terkait Universitas Terbuka kepada customer. Akan tetapi, dalam menjalankan tugas-tugas tersebut ternyata ada beberapa kendala yang dialami oleh pegawai front desk. Kendala tersebut terbagi atas dua bagian, yakni kendala internal dan eksternal.

Kendala Internal, adalah memahami keluhan customer adalah kendala yang lebih sering terjadi di dalam diri seorang pegawai front desk. TKT front desk adalah pegawai 色 $h t t p: / / m a h e s a i n s t i t u t e . w e b . i d / o j s 2 / i n d e x . p h p / j e h s s$ 
baru di lingkungan UT, sehingga ia memerlukan waktu dan proses yang cukup lama dalam mempelajari seluk beluk UT. Hal ini tidak terlepas dengan banyaknya jumlah keluhan perharinya yang tidak sebanding dengan waktu proses belajar pegawai front desk untuk memahami UT. Mereka harus belajar dan memahami semua permasalahan customer, melaksanakan pekerjaan yang kadangkala bukan menjadi tupoksinya, menunggu solusi yang diberikan oleh bagian Pelma dan menyampaikannya kembali kepada customer. Di waktu luangnya, pegawai front desk dituntut -paling tidakmemahami isi katalog Sistem Penyelenggaraan Program Pembelajaran di UT agar dapat memberikan solusi kepada customer yang umumnya didominasi oleh mahasiswa.

Selain kendala yang berasal dari diri sendiri, adapula kendala yang berasal dari beberapa keluhan mahasiswa yang masih belum dipahami dengan jelas oleh pegawai front desk untuk ditemukan solusinya. Salah satu permasalahan tersebut yakni ketika menangani kasus nilai mata kuliah berpraktek dan nilai TAP yang tidak keluar. Alur dari tutorial pada mata kuliah tersebut masih dipelajari oleh pegawai front desk.

Bila merujuk pada katolog UT (2015), pada poin praktik dan praktikum bahwa aspek yang dinilai dalam praktik dan praktikum adalah proses pelaksanaan praktik/ praktikum, laporan praktik/praktikum, dan atau ujian praktik/praktikum. Skor dari praktik/praktikum untuk mata kuliah berpraktek/berpraktikum mempunyai kontribusi $50 \%$ terhadap nilai akhir mata kuliah jika UAS mencapai skor minimal 30. Sedangkan untuk mata kuliah praktik/praktikum, skor praktek/praktikum mempunyai kontribusi $100 \%$.

Permasalahan yang kerap menjadi kendala pegawai front desk adalah menemukan solusi atas permasalahan mata kuliah berpraktek tersebut karena didasari pada tiga poin penilaian yakni proses pelaksanaan, laporan, dan ujian praktik/praktikum. Kebingungan pegawai front desk tidak lepas dari peran serta PJW, pengelola, pengawas ujian, serta tutor. Kesilafan bisa saja terjadi diantara keempat personal tersebut manakala mahasiswa merasa sudah menyelesaikan tugas dengan baik tetapi tidak menerima nilai.

Selain itu, terdapat mata kuliah TAP yang kerap dikeluhkan mahasiswa yang bertujuan untuk mengukur kemampuan mahasiswa secara komprehensif dalam suatu bidang ilmu pada program studi jenjang D-IV dan S1. Materi TAP mencakup beberapa mata kuliah pendukung dari setiap program studi. Sejak 2015.1 berlaku ketentuan bahwa nilai akhir TAP/PKP berasal dari 80\% skor TAP/PKP dan 20\% dari Karya Ilmiah 
(Karil). Jika mahasiswa tidak mempunyai skor Karya Ilmiah, maka nilai akhir TAP/ PKP hanya berasal dari 80\% skor TAP/ PKP. Karya Ilmiah tersebut dapat diunggah pada aplikasi unggal Karil UT (http://karil.ut.ac.id).

Permasalahan yang pernah terjadi ialah tidak ditemukannya berkas TAP/PKP mahasiswa baik di UPBJJ-UT maupun di Pokjar. Semisal pada Pokjar X pernah terjadi kehilangan berkas pada satu kelas yang mengakibatkan nilai tidak dapat diperoleh oleh mahasiswa. Solusi yang dapat ditawarkan sementara oleh pegawai front desk adalah melaporkan ke bagian Pelma, PJW, koordinator BBLBA dan mahasiswa harus mengirimkan ulang laporan/ berkas yang dituntut pada mata kuliah TAP.

Selanjutnya, kendala yang dialami pegawai front desk adalah terkait adanya siklus perubahan penanggung jawab wilayah (PJW) di UPBJJ-UT Medan. Selama menjalani tugas menjadi pegawai front desk terdapat permasalahan yang kerap menjadi kebingunan pegawai front desk. Sebagai contoh ialah kasus DS yang terjadi pada mahasiswa X di Pokjar B yang ditanggungjawabi oleh PJW Y. Ketika mahasiswa melakukan komplain karena nilainya tidak keluar di masa studi semester lalu yang dikelola oleh PJW Y, pegawai front desk mendapati kesulitan. Pasalnya, PJW Y tidak merasa memiliki tanggung jawab lagi untuk menyelesaikan perkara mahasiswa $\mathrm{X}$ di Pokjar B, karena pada semester ini ia ditempatkan di Pokjar A. Artinya terjadi proses lepas tangan di kalangan PJW, yang membuat permasalahan mahasiswa X belum bisa diselesaikan. Sedangkan pegawai front desk tidak memiliki akses untuk melaporkan langsung masalah/ keluhan mahasiswa tersebut ke UT Pusat.

Baik Koordinator Registrasi dan Ujian maupun Koordinator BBLBA biasanya melakukan pergantian atau perubahan-perubahan wilayah pada beberapa Penanggung Jawab Wilayah (PJW). Hal ini dilakukan dalam rangka untuk senantiasa mempertahankan kualitas PJW agar bersih dari dugaan-dugaan praktek uang. Sehingga karena adanya siklus perubahan PJW di beberapa pokjar, cenderung timbul sikap lepas tangan sebagaimana diurai pada contoh di atas.

Selain itu, acapkali berbagai permasalahan hanya diselesaikan oleh seorang bagian Pelma saja. Pelma ialah singkatan dari PELayanan MAhasiswa, yaitu layanan yang diberikan oleh Universitas Terbuka pada setiap kantor UPBJJ agar dapat menjangkau keluhan mahasiswa baik keluhan yang bersifat akademik maupun pemberian informasi tentang Universitas Terbuka. Banyaknya keluhan yang masuk ke seorang bagian Pelma 
memberikan dampak semakin lamanya solusi pemecahan masalah dapat diterima oleh mahasiswa. Biasanya hal - hal tersebut berkaitan dengan nilai mata kuliah yang bermasalah/ tidak keluar.

UT sendiri memberikan pelayanan ke setiap kabupaten melalui “Pengelola”, yang mengelola setiap data mahasiswa baik mahasiswa aktif maupun mahasiswa baru yang akan mendaftar menjadi mahasiswa UT. Setelah registrasi, umumnya pengelola akan membawa data-data mahasiswa ke bagian PELayanan Mahasiswa di kantor - kantor UPBJJ. Permasalahan yang terjadi di ranah pengelola adalah tidak lengkapnya berkas yang dilaporkan pengelola kepada petugas UPBJJ-UT sehingga pada akhir semester, mahasiswa tidak dapat menerima hasil studinya.

Kendala Eksternal yang ada adalah ketika menghadapi Karakter Customer yang beragam. Pegawai front desk kadang kala terkendala dalam menghadapi karakter customer yang beragam apalagi customer dengan karakter yang kurang baik dan tidak sopan. Berikut ini adalah beberapa tipe/ karakter customer yang harus dihadapi oleh pegawai front desk dalam melakukan pelayanan prima.

Pertama, tipe complainer dengan karakteristik suka mencari-cari kesalahan, banyak berbicara dan mendominasi pembicaraan, tidak memiliki kesabaran, tidak pernah puas, suka menyalahkan orang lain, dan selalu merasa benar. Tipe customer seperti ini pernah dihadapi oleh pegawai front desk. Sesuai dengan pelatihan yang pernah dijalani oleh seluruh pegawai front desk di UT, maka untuk menangani customer dengan tipe seperti ini ialah memperhatikan apa yang customer katakan, memberikan kesempatan untuk berbicara terlebih dahulu, harus jelas dalam menjelaskan dan mengelaborasi, jangan menyela, dan menyampaikan jawaban secara teratur dan sistematis.

Kedua, tipe controller dengan karakteristik ingin selalu bersikap dominan, suka menantang tanggapan yang kita berikan dengan pendapat sendiri, mengintimidasi, membawa nama atasan/pejabat tertentu untuk menekan/menakut-nakuti, selalu merasa benar, dan tidak memiliki kesabaran. Tipe seperti ini juga pernah dialami pegawai front desk. Sehingga dalam menyikapi karakter tersebut, ada beberapa cara yang dapat dilakukan, diantaranya fokus pada masalah dan tidak terganggu oleh perilaku customer, mendengarkan dan mencoba untuk memahami apa yang ada dalam pikiran controller, memberi kesempatan untuk mengutarakan pendapatnya terlebih dahulu, menghargai 
pendapatnya, sebelum pegawai front desk menawarkan pendapat yang lain, dan menyampaikan pendapat yang bermanfaat dengan cepat dan sistematis.

Ketiga, tipe socialiser dengan karakteristik ceria, ramah, dan suka berbicara, memiliki kepribadian dan mendukung, senang mendapat pujian, senang menjalin relasi dan keakraban, senang bertemu orang langsung, dan memiliki kecenderungan suka berbicara keluar jalur. Tipe seperti ini lebih sering ditemui oleh pegawai front desk dan hampir dengan mudah ditangani oleh pegawai front desk. Umumnya mereka (pegawai front desk) memberikan solusi dengan menerapkan layanan prima seperti meluangkan sedikit waktu untuk membangun hubungan selama transaksi, membicarakan hal-hal pribadi yang positif, memberikan penghargaan dan pujian, memperhatikan ekspresi wajah dan bahasa tubuhnya, meluangkan waktu untuk memberi penjelasan dan selalu melakukan cek terhadap pemahamannya.

Keempat, tipe know it all dengan karakteristik seseorang yang berpikir memiliki jawaban atas semua pertanyaan, suka menyombongkan diri, banyak berbicara dan bertanya, menguji jawaban pegawai front desk dan akan memberikan pendapatnya sendiri, senang mengintimidasi, dan senang diperhatikan. Tipe seperti ini tidak banyak ditemukan selama terlaksananya kegiatan layanan front desk. Tetapi dalam menghadapi tipe customer seperti ini, pegawai front desk tetap berpedoman pada standar layanan akademik bahwa ia harus menyiapkan fakta-fakta dan data, menyimak dan mengambil kata-kata kunci dari customer, mengajukan pertanyaan-pertanyaan, dan benar-benar memahami jawaban yang dilontarkan customer.

Kelima, tipe shy dengan karakteristik seseorang yang tidak yakin apa yang diinginkan, memberikan jawaban yang tidak jelas, setuju dan menerima jawaban pegawai front desk dan hampir tanpa pertimbangan, tidak dapat menjelaskan atau mengelaborasi, tampak bingung dan tidak percaya diri. Tipe seperti ini lebih sering ditemui pegawai front desk. Mereka ialah mahasiswa baru pemalu yang umumnya tidak memahami sistem penyelenggaraan pembelajaran di UT. Adapun cara menangani tipe mahasiswa seperti ini ialah berbicara dengan jelas dan perlahan-lahan padanya, melakukan cek pemahaman dengan menanyakan apakah customer mengerti dengan apa yang disampaikan, mengulangi jawaban dan poin-poin inti, bersabar dan memberikan waktu untuk menjelaskan, dan meyakinkan customer dengan menyimak dan mendorongnya untuk berbicara. 
Terakhir, keenam ialah tipe alien dengan karakteristik seseorang yang masih awam atau staf baru, tidak paham dengan prosedur, tidak paham dengan lingkungan sekitarnya, seperti orang asing yang berbicara dalam bahasa sendri, dan merasa tidak berdaya. Mereka ini lah tipe customer yang benar-benar tidak paham dengan prosedur yang diberlakukan oleh UT. Umumnya mereka berasal dari luar kota dan belum pernah menginjak UPBJJ-UT. Adapun cara menanganinya ialah memperhatikan ekspresi wajah dan bahasa tubuh customer, menjelaskan secara perlahan, melakukan cek pemahaman kembali, menjaga postur tenang dan memberi perhatian, dan membuat customer merasa aman dengan isyarat verbal dan non verbal.

\section{Keluhan dan Solusi Pemecahan Permasalahan Customer oleh Pegawai Front Desk}

Berdasarkan wawancara yang dilakukan pada seorang pegawai front desk, diutarakan bahwa banyak keluhan mahasiswa berasal dari Pokjar Nias. Terdapat salah satu pokjar yang pengelolanya tidak aktif sehingga banyak persoalan administrasi yang tidak terkelola. Selain itu terkait kasus DS, banyak didapati pada mahasiswa Pokjar Asahan, Sei Balai, dan Batubara. Salah satu pokjar sedang dalam pantauan UPBJJ-UT karena terindikasi banyaknya praktek uang yang dilakukan pengelola. Misalnya pengelola mengutip dana wisuda sejumlah Rp.1.000.000,-/mahasiswa (calon wisudawan). Padahal sesuai dengan katalog Sitem Penyelenggaraan Prodi, biaya wisuda UT sudah termasuk pada biaya perkuliahan yang dibayarkan setiap semesternya.

Adanya front desk ternyata membantu UPBJJ-UT Medan dalam melakukan pengawasan di ranah pokjar. Mahasiswa berduyun-duyun melapor sehingga diharapkan terjadi perbaikan administrasi pendidikan di lingkup pokjar.

Pada kasus yang terjadi di UPBJJ-UT Medan, ada sekitar 66 orang di masa 2016.1 melaporkan keluhannya karena bermasalahnya nilai untuk mata kuliah TAP (44 orang) dan mata kuliah berpraktek (14 orang). TAP diselenggarakan bagi mahasiswa program sarjana (S1) menjelang penyelesaian studinya, dengan tujuan untuk memverifikasi penguasaan secara komprehensif terhadap suatu bidang ilmu tertentu. Sebagaimana telah diuraikan pada sub bab sebelumnya bahwa apabila terdapat kekurangan dari salah satu berkas laporan pada mata kuliah TAP, maka berdampak pada tidak keluarnya nilai mahasiswa. Adapun Tugas Akhir Program (TAP) bersumber pada nilai ujian TAP dan 
tugas dan partisipasi Tuton TAP. Skor tutorial akan berkontribusi terhadap nilai akhir TAP jika skor TAP minimal 30.

Selain itu, terdapat kasus tidak keluarnya nilai pada mata kuliah berpraktik. Beberapa mata kuliah yang ditawarkan di UT mewajibkan praktik atau praktikum. Praktik adalah kegiatan yang menuntut mahasiswa untuk menerapkan konsep, prinsip, prosedur, dan keterampilan dalam situasi nyata atau buatan secara terprogram dan terbimbing atau mandiri. Sedangkan praktikum adalah kegiatan yang menunut mahasiswa untuk melakukan pengamatan, percobaan, atau pengujian suatu konsep atau prinsip materi mata kuliah yang dilakukan di dalam atau di luar laboratorium. Kegiatan praktik atau praktikum dilaksanakan di bawah bimbingan instruktur/ supervisor/ pembimbing kecuali PS agribisnis FMIPA, praktik dilakukan secara mandiri oleh mahasiswa dengan menggunakan prosedur praktik yang baku. Pelaksanaaan praktik dan praktikum harus dilakukan mahasiswa secara berkelompok dengan menggunakan fasilitas kit, dan senantiasa berkoordinasi dengan UPBJJ.

Terdapat kategori penilaian dari mata kuliah praktik dan praktikum. Kegiatan praktik dan praktikum dikelompokkan ke dalam 4 kategori mata kuliah sebagai berikut: 1) Mata kuliah praktik yaitu mata kuliah yang nilai akhirny hanya ditentukan oleh nilai yang diperoleh dari hasil kegiatan praktik; 2) Mata kuliah praktikum yaitu mata kuliah yang nilai akhirnya hanya ditentukan oleh nilai yang diperoleh dari hasil kegiatan praktikum; 3) Mata kuliah berpraktik yaitu mata kuliah yang nilai akhirnya ditentukan oleh nilai praktik dan UAS; 4) Mata kuliah berpraktikum yaitu mata kuliah yang nilai akhirnya ditentukan oleh nilai praktikum dan UAS.

Keluhan yang dilaporkan pada kasus tidak keluarnya nilai di mata kuliah berpraktek ini hanya sedikit terjadi dibandingkan kasus yang lain. Hal ini terjadi dimungkikan akibat tutor tidak melaporkan nilai mahasiswa ke PJW atau kemungkinan kesalahan tutor dalam mengetik nama atau NIM mahasiswa tersebut pada laporannya sehingga berakibat pada kesalahan data dan tidak keluarnya nilai tersebut. Atau PJW tidak melakukan recheck ulang pada hasil nilai yang dikirimkan oleh tutor. Contoh mata kuliah berpraktek ialah PKM (pemantapan Kemampuan Mengajar).

\section{Saran dan Harapan Customer (Mahasiswa) untuk Peningkatan Kualitas UT}


Berikut ini adalah beberapa saran dan harapan yang diinginkan oleh customer dalam rangka penyelesaian studi di Universitas Terbuka. Pertama, mahasiswa berharap semua mata kuliah di UT dapat ditutorialkan. Belajar mandiri menjadi salah satu kesulitan karena tidak hanya disebabkan oleh padatnya jadwal pekerjaan mahasiswa, tetapi juga kurangnya motivasi dari diri sendiri dan usia yang sudah tua untuk dapat fokus mempelajari dan membaca modul secara mandiri.

Kedua, mahasiswa mengeluhkan nilai yang cenderung sulit untuk diperoleh, sehingga mahasiswa berharap agar nilai yang diberikan jangan terlalu rendah. Umumnya hal ini terjadi di kalangan mahasiswa yang menginjak usia lanjut. Kesulitan dalam belajar di usia tua menjadi salah satu kendala dalam menempuh pendidikan di UT. Oleh karena itu, customer berharap agar soal yang diujiankan dalam UAS tidak terlalu sulit dan terdapat jawabannya di dalam modul. Hal ini pernah dikeluhkan mahasiswa karena terdapat satu mata kuliah yang diujiankan dalam UAS, tetapi materi yang terdapat pada soal tidak terdapat ulasannya di dalam modul, juga soal tidak sesuai dengan yang ditutorialkan. Hal ini tentu di luar jangkauan mahasiswa dalam menjawab soal.

Ketiga, mahasiswa berharap dapat memeroleh dana beasiswa, baik dari UT maupun melalui kerjasama yang dijalin UT dengan berbagai institusi negeri dan swasta. Keempat, komunikasi yang baik antara tutor dan mahasiswa juga menjadi salah satu tolok ukur mudah atau tidaknya pembelajaran dapat diserap oleh mahasiswa, sehingga mahasiswa mengharapkan saat tutorial baik TTM maupun tuton dapat dihadirkan tutor yang kapabel dan berkarakter. Hal ini sebagaimana diutarakan oleh Damayanti salah satu mahasiswa UT di Pokjar Langkat berikut ini: "Maunya tutor yang dipilih jangan yang pemarah, suka telat datang, dan kasar. Soalnya kami pernah mengalaminya. Proses belajar jadi gak nyaman dan tertekan. Kami selalu saja dianggap salah.”

Kelima, tutor dan pengelola jangan sampai khilaf dalam mengirimkan atau melaporkan tugas-tugas perkuliahan, sehingga mahasiswa tidak mengalami keterhambatan dalam pemerolehan nilai. Keenam, tempat tutorial terlalu jauh sehingga mahasiswa senantiasa was-was dalam belajar sebab harus memikirkan bagaimana dapat tiba di lokasi tutorial dengan tidak terlambat dan menyelesaikan tutorial dengan cepat. Hal inilah yang kadang kala menjadi penghambat untuk kelancaran proses tutorial.

Ketujuh, dengan adanya pegawai front desk, mahasiswa merasa sangat terbantu karena berbagai permasalahan dapat dituntaskan dengan segera. Mahasiswa yang 
mengalami penundaan nilai, tidak lagi merasakannya karena berkas awal registrasi mahasiswa telah terpenuhi. Mahasiswa dilancarkan dalam proses legalisir ijazah tanpa harus menambah biaya. Mahasiswa senantiasa diberikan solusi pada setiap permasalahan dan memerolah update informasi terbaru tentang UT.

\section{SIMPULAN}

Layanan baru yakni pengangkatan TKT front desk diperlukan dalam rangka pengoptimalan kinerja yang sesuai dengan visi, misi, tujuan, dan sasaran Universitas Terbuka. Peran pegawai front desk di UPBJJ-UT Medan sangat penting karena sepanjang masa 2016.1, setidaknya ada 1.005 orang mahasiswa yang terbantu dalam penyelesaian masalah studinya. Melalui penempatan front desk di tiap UPBJJ, telah membantu kelancaran berbagai permasalahan yang dialami mahasiswa dalam penyelesaian studinya. Adapun kendala yang dialami pegawai front desk dalam melaksanakan tugasnya terdiri dari kendala internal yakni dalam menemukan solusi dari permasalahan/keluhan customer yang masih dipelajari pegawai front desk, melaksanakan pekerjaan yang kadangkala bukan menjadi tupoksinya, adanya siklus perubahan PJW yang membuat permasalahan kian rumit karena ada PJW yang lepas tangan dan menganggap masalah mahasiswa bukan merupakan tanggung jawabnya lagi.

Sedangkan kendala eksternal ialah menghadapi karakter customer yang beragam.

\section{DAFTAR PUSTAKA}

Barata, A.A. (2003). Dasar-dasar Pelayanan Prima. Jakarta. PT Gramedia Pustaka. Berry, D. (2003). Pokok-pokok Pikiran Dalam Sosiologi. Jakarta: Raja Grafindo Persada Horton, B.P. \& Hunt, L.C. (1987). Sosiologi Jilid I, Jakarta: Erlangga.

Kamus Besar Bahasa Indonesia Edisi Kedua. (1996). Jakarta. Balai Pustaka 3685

Maddy, K. (2009). "Pengertian Pelanggan". Artikel. Diakses di http://ammarawirausaha.blogspot.com/2009/10/pengertian-pelanggan.html, pada tanggal 06 Februari 2016.

Pendit, N.S. (2002). Ilmu Pariwisata Sebuah Pengantar Perdana. Jakarta: PT. Pradnya Paramita.

Rahmayanty. (2013). Strategi Peningkatan Retribusi (Jasa) Pasar Niaga Daya Di Kota Makassar. Universitas Hasanuddin Fakultas Ilmu Sosial Dan Ilmu Politik Jurusan Ilmu Administrasi

Sampara, L.S.. (2001). Pengembangan pelaksanaan pelayanan prima. Jakarta. Lembaga Administrasi Negara Republik Indonesia.

Wahjono, S.I. (2010). Manajemen Pemasaran Bank.Yogyakarta. Graha Ilmu

Soekanto, S. (2002), Teori Peranan, Jakarta, Bumi Aksara.

Suparman, A. Zuhairi, A. (2004). Pendidikan Jarak Jauh teori dan praktek. Jakarta. Pusat penerbitan Universitas Terbuka.

Tim Universitas Terbuka. (2010). Rencana Strategis 2010-2021, Rencana Operasional 2010-2013 Universitas Terbuka. Jakarta: universitas Terbuka . (2015). Katalog Sistem Penyelenggaraan Program Non Pendas Universitas Terbuka 2015. Jakarta: Universitas Terbuka. 